\title{
Estrogen receptor alpha localization in the testes of men with normal spermatogenesis
}

\author{
Eliza Filipiak $^{1}$, Dagmara Suliborska ${ }^{1}$, Maria Laszczynska ${ }^{2}$, \\ Renata Walczak-Jedrzejowska ${ }^{3}$, Elzbieta Oszukowska ${ }^{3}$, Katarzyna Marchlewska ${ }^{1}$, \\ Krzysztof Kula ${ }^{3}$, Jolanta Slowikowska-Hilczer ${ }^{1}$
}

\author{
${ }^{1}$ Department of Reproductive Endocrinology, Medical University of Lodz, Poland \\ ${ }^{2}$ Department of Histology and Developmental Biology, Pomeranian Medical University, Szczecin, Poland \\ ${ }^{3}$ Department of Andrology, Medical University of Lodz, Poland
}

\begin{abstract}
It is known that estrogens act on the male reproductive tract by binding to estrogen receptors (ER) $\alpha$ and $\beta$. However, studies on ER localization in the human testis are discordant. The aim of this study was to investigate the localization of $\mathrm{ER} \alpha$ in the testes of adult men with normal spermatogenesis. Semen analysis of ten adult men revealed azoospermia. FSH, LH and testosterone serum concentrations were within normal values, and the volume of the testes was normal, hence obstructive azoospermia was suspected. The tissues from testicular surgical biopsies were fixed in Bouin's fluid and embedded in paraffin. Assessments of the seminiferous epithelium (scoring 10 to -1), the number of Leydig cells (scoring 1 to 5), the areal fraction of intertubular space (IS), measurements of seminiferous tubule diameter, and the thickness of the tubular wall, were performed on microscopic sections. Immunohistochemical staining was applied with monoclonal antibodies against ER $\alpha$. The mean spermatogenesis score was 10 points; IS - 30.6 $\pm 8.1 \%$; seminiferous tubule diameter $-193.9 \pm 19.4 \mu \mathrm{m}$; thickness of tubular wall $-7.44 \pm 1.1 \mu \mathrm{m}$; number of Leydig cells $-1.6 \pm 1.1$ points. Immunohistochemical staining showed the localization of ER $\alpha$ to be in the Sertoli and Leydig cell cytoplasm, while ER $\alpha$ was absent in germ cells. The results of testicular tissue analysis confirmed its normal structure and normal, full spermatogenesis. The presence of ER $\alpha$ in Sertoli and Leydig cells in normal human testis demonstrated in this study suggests that estrogens may affect testicular function. (Folia Histochemica et Cytobiologica 2012, Vol. 50, No. 3, 340-345)
\end{abstract}

Key words: human testis, estrogen receptor alpha, spermatogenesis, Sertoli cell, Leydig cell, immunohistochemistry, morphometry

\section{Introduction}

Estrogens act on the target tissue by means of binding to an estrogen receptor (ER), which is a member of the nuclear receptor superfamily. Upon binding to ER, the ligand causes conformational changes in the receptor structure, followed by its dimerization. The activated receptor interacts with DNA, specifically with estrogen responsive elements (EREs), resulting

\footnotetext{
Correspondence address: J. Słowikowska-Hilczer,

Department of Reproductive Endocrinology,

Medical University of Lodz,

Sterlinga Str. 5, 91-425 Lodz, Poland;

e-mail: jolanta.slowikowska-hilczer@umed.lodz.pl
}

in the transcription of target genes [1]. Nowadays, it is known that ERs can also modulate gene expression without direct binding to DNA [2].

Two main types of ER can be distinguished: $\alpha$ and $\beta$ (also called ER1 and ER2, respectively). Both ER types consist of six distinct regions (A-F). ER $\alpha$ and $\operatorname{ER} \beta$ are, to some extent, similar in structure and have high amino acid homology, especially in the DNA-binding and ligand-binding domains, which correspond to regions $\mathrm{C}$ and $\mathrm{E}$, respectively. Although most ligands have similar binding and transcriptional potency for $\operatorname{ER} \alpha$ and $\operatorname{ER} \beta$, some ligands are more specific for one ER type. For example, tetrahydrochrysene is an agonist of $\mathrm{ER} \alpha$ and an antagonist of $\mathrm{ER} \beta$, and aryl-substituted pyrazole shows a higher binding 
affinity for $\mathrm{ER} \alpha$ and stimulates it more than 100 times more effectively than $\operatorname{ER} \beta[3]$.

Generally, ERs are abundantly distributed in many tissues and organs such as the central and peripheral nervous system, skeleton, lungs, and the cardiovascular and reproductive systems of females and males [4-6]. Studies with ER knock-out (ERKO) mice showed that a lack of receptors leads to infertility [7] and deficient sexual behaviour in males [8]. Both ER types are widely distributed in the male reproductive system, although ER $\beta$ seems to be prevalent. Both ER types are present in the epididymis of pigs, rats and monkeys [9-11], however, in humans, ER $\beta$ seems to be more prevalent [12]. The prostate in humans and rats contains mainly $\mathrm{ER} \beta$, while $\mathrm{ER} \alpha$ is rarely detectable $[10,13]$.

The exact localization of $\operatorname{ER} \alpha$ and $\operatorname{ER} \beta$ in the testis is still uncertain and seems to be species- and agedependent, e.g. $\operatorname{ER} \alpha$ and $\operatorname{ER} \beta$ localization changes during the lifespan of rodents and stallions $[14,15]$. According to Hejmej et al. [16] the presence of $\operatorname{ER} \alpha$ in stallions is limited to Leydig cells during the neonatal and peripubertal periods of life. In the bank vole (independently of the animal's age) ER $\alpha$ presence was observed in Leydig cells while $\operatorname{ER} \beta$ was present in Sertoli cells, and also in the nuclei of spermatocytes and elongated spermatids of animals exposed to long light cycles [17]. Recently, it has been shown that $\mathrm{ER} \alpha$ was present in spermatids and Sertoli cells of descended testes, and also in Leydig cells of cryptorchid testes of rats [18]. In turn, Pelletier et al. [19] localized ER $\alpha$ in rats in the nuclei of Leydig cells, as well as in round spermatocytes and spermatids. $\mathrm{ER} \beta$ was only detected in Sertoli cell nuclei. Other authors have observed expression of ER $\beta$ in rat germ and somatic cells (Leydig or Sertoli cells) [20, 21]. During the perinatal period $\mathrm{ER} \beta$ mRNA and $\mathrm{ER} \beta$ protein were demonstrated in fetal germ cells, i.e. gonocytes (data for rats aged four days), in spermatogonia A and pachytene spermatocytes (data for rats aged 10-26 days) [21].

Regarding human models, Makinen et al. [22] showed that $\operatorname{ER} \beta$ was the only ER type observed in the human testis (in nuclei of spermatogonia, spermatocytes and early spermatids). Enmark et al. [23] confirmed the localization of $\operatorname{ER} \beta$ in spermatids, while Cavaco et al. [24] found that $\operatorname{ER} \beta$ was localized in Leydig cells, spermatocytes, spermatids and spermatozoa. Shapiro et al. [25] found both ER $\alpha$ in Leydig cells and $\mathrm{ER} \beta$ in germ and Leydig cells of human fetal testis. In contrast, Boukari et al. [26] demonstrated the presence of only $E R \beta$ in human fetal testis since $\mathrm{ER} \alpha$ was not detected in their study.

The inconsistency of the reports on ER $\alpha$ localization in the human testis (for a review, see $[27,28]$ ) may be due to the lack of homogeneity of the examined groups, i.e. different abnormalities in spermatogenesis. The aim of this study was to determine the testicular localization of $\mathrm{ER} \alpha$ in young adult men with confirmed normal spermatogenesis.

\section{Material and methods}

The retrospective study was performed with the approval of the Bioethical Committee of the Medical University of Lodz (Poland). Ten men, aged 25-39 years (median 32), were included in this study. Their clinical documentation was obtained from the Outpatients Clinic of Andrology and Reproductive Endocrinology in Lodz (Poland), to which the patients were referred due to infertility.

In all subjects, semen analysis was performed according to WHO guidelines [29]. The azoospermia was assessed in each patient; otherwise all patients were healthy. In all patients, the testicular volume measured by means of ultrasonography was normal (>12 ml), and the structure of the testes was homogeneous. Serum concentrations of hormones were measured in the Department of Hormonal Diagnostics in Lodz (Poland) using a chemiluminesence immunoassay (Immulite 1000, DPC, USA). The detection limits were $0.5 \mathrm{nmol} / /$ for total testosterone, $0.1 \mathrm{IU} / \mathrm{L}$ for FSH, and $0.1 \mathrm{IU} / \mathrm{L}$ for $\mathrm{LH}$. Reference values in the Department of Hormonal Diagnostics are as following: testosterone $7.5-28.2 \mathrm{nmol} / \mathrm{l}, \mathrm{FSH}-1.55-9.47 \mathrm{mIU} / \mathrm{ml}$ and $\mathrm{LH}-$ $0.83-15.5 \mathrm{mIU} / \mathrm{ml}[30]$.

All patients underwent unilateral or bilateral surgical testicular biopsy in the course of the diagnostic procedure for infertility. Archival material of these patients' testes, embedded in paraffin and stored in the Department of Andrology and Reproductive Endocrinology, Medical University of Lodz, was used for the study.

Histology and immunohistochemistry. Tissues were fixed in Bouin's solution and embedded in paraffin. Each biopsy was completely serially sectioned. The sections, $5 \mu \mathrm{m}$ thick, were stained with hematoxylin and eosin and examined using a light microscope (Eclipse E 600, Nikon, Japan).

For immunohistochemistry, the sections were heated in citrate buffer, $\mathrm{pH}=9.0$ for $30 \mathrm{~min}$. in a water bath at $96^{\circ} \mathrm{C}$. The sections were next incubated for $30 \mathrm{~min}$ at room temperature in a humidified chamber with monoclonal mouse anti-human ER $\alpha$ antibody (N 1575, Dako Cytomation, Glostrup, Denmark). The detection of the anti-ER $\alpha$ antibody was performed using a Dako LSAB 2 KIT/HRP kit. Aminoethylocarbazole (AEC substrate chromogen) was used to visualize the immunohistochemical reaction. Finally, the sections were counterstained with Mayer's hematoxylin. After each step, the sections were rinsed with Tris-buffered saline (TBS). The negative control sections were incubated with TBS instead of the primary antibody. Sections of ovarian tissues from postmenopausal women served as positive control [31]. 
Assessment of spermatogenesis and Leydig cells. Spermatogenesis and the seminiferous epithelium were scored on a scale of -1 to 10 according to a modification of De Kretser and Holstein's method [32], presented in a previous study [33]. A score of 10 points was considered to be full, intact spermatogenesis, while a lower score indicated a deteriorating seminiferous epithelium. In each biopsy, 50-100 crosssections of seminiferous tubules were evaluated and a mean number of points was assigned to the biopsy specimen.

The number of Leydig cells in the triangular intertubular spaces was assessed on a scale of 1-5 according to Guminska et al. [33]. Based on observations from our own and other studies, a number of Leydig cells higher than 2 points was considered to be abnormal [34]. In each biopsy, 100 triangular intertubular spaces were evaluated and a mean number of points was assigned to the biopsy specimen.

Morphometry. Morphometric analyses were performed using LxAND v3.60HM image analysis software (Logitex, Lodz, Poland). Seminiferous tubule diameter, thickness of tubular membrane and the areal fraction of intertubular space (IS) were evaluated. The IS value indicates the percentage area of the intertubular compartment within the area of the histological section of the testicular biopsy [35]. The microscopic image at $100 \times$ magnification was covered by a square lattice containing 441 intersections. The number of intersections projecting on the intertubular spaces was counted by a systematic movement across the grid over the entire tissue section. The IS value was calculated by dividing the number of intersections which fell on the intertubular spaces by the number of intersections within the whole field of vision at the same magnification, and multiplied by 100 .

All the measurements were performed in ten randomly-selected histological sections of one gonad in each patient and are shown as a mean \pm SD. The following values were recognized as abnormal: tubular diameter $<150 \mu \mathrm{m}$, thickness of tubular wall $>10 \mu \mathrm{m}$, IS $>40 \%$. The normal values of the diameter of seminiferous tubules, thickness of tubular wall and interstitial spaces were defined based on previous reports [33, 34, 36, 37].

Statistics. All statistical analyses were performed using Statistica 8.0 software (StatSoft, Krakow, Poland).

\section{Results}

Measurements of FSH, LH and testosterone serum concentrations revealed normal values (Table 1).

The assessment of the spermatogenesis score and Leydig cell score, as well as the morphometric analysis of testicular structure, revealed values typical for normal adult testes (Table 1) [33, 36, 37].

$\mathrm{ER} \alpha$ immunostaining was found in the cytoplasm of Sertoli and Leydig cells (Figure 1). The nuclei of germ cells (spermatogonia, spermatocytes, round and elongat-
Table 1. Serum hormone concentrations, testicular volume and morphometry of testicular structures in ten adult men with obstructive azoospermia

\begin{tabular}{|l|c|}
\hline Parameters & Mean \pm SD \\
\hline FSH [IU/L] & $5.28 \pm 2.7$ \\
\hline LH [IU/L] & $4.6 \pm 2.6$ \\
\hline Testosterone [nmol/L] & $15.95 \pm 6.0$ \\
\hline Testicular volume [ml] & $16.8 \pm 3.2$ \\
\hline Spermatogenesis advance (points) & 10 \\
\hline Seminiferous tubules diameter $[\mu \mathrm{m}]$ & $193.9 \pm 19.4$ \\
\hline Thickness of tubular membrane $[\mu \mathrm{m}]$ & $7.44 \pm 1.1$ \\
\hline Areal fraction of intertubular spaces $(\%)$ & $30.6 \pm 8.1$ \\
\hline Number of Leydig cells (points) & $1.6 \pm 1.1$ \\
\hline
\end{tabular}

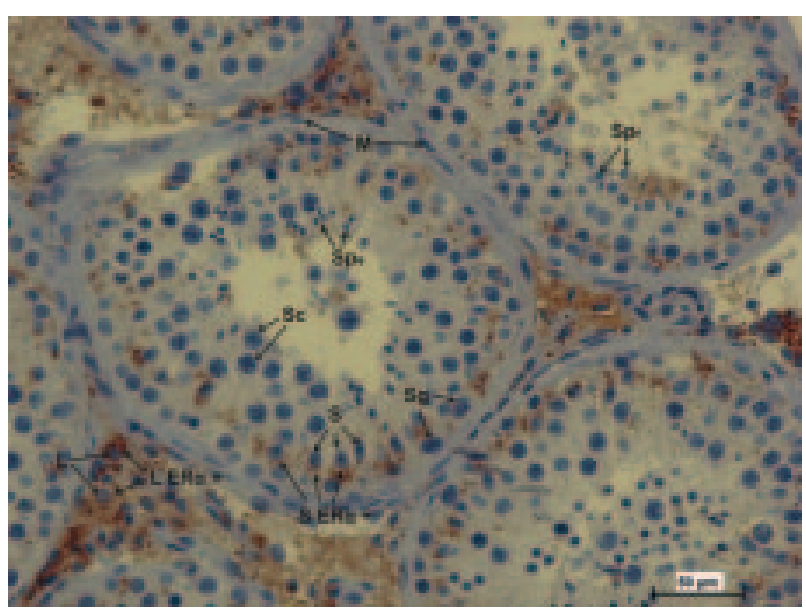

Figure 1. Positive ER $\alpha$ immunostaining of testis (red color) with normal structure and full spermatogenesis is clearly visible in Sertoli and Leydig cells' cytoplasm. Some immuno- reactivity seen in the lumen of the tubule or nearby presents an artifact

$\mathrm{Sg}$ - nuclei of spermatogonia; Sc - nuclei of spermatocytes; Spr — nuclei of round spermatids; Spe — nuclei of elongated spermatids; $\mathrm{M}$ - nuclei of myoid cells; L nuclei of Leydig cells; S - nuclei of Sertoli cells; L-ER $\alpha^{+}-$ staining positive for $\mathrm{ER} \alpha$ in Leydig cells cytoplasm; S-ER $\alpha^{+}$ — staining positive for $\mathrm{ER} \alpha$ in Sertoli cells cytoplasm

ed spermatids, spermatozoa) were not immunoreactive for $\mathrm{ER} \alpha$. Some immunoreactivity seen in the lumen of the tubule or nearby has been assessed as an artifact due to reallocation of seminiferous epithelium from another part of the tubule during testicular biopsy.

\section{Discussion}

Our study revealed ER $\alpha$ immunolocalization in Sertoli and Leydig cells in human testes with normal structure and full spermatogenesis. This is in accor- 
dance with the results of Taylor and Al-Azzawi [38] who found $\mathrm{ER} \alpha$ in Sertoli and Leydig cells of humans. Nevertheless, the results of studies on $\mathrm{ER} \alpha$ localization in testes shown in the literature are discordant. They can vary depending on the method used to determine the presence of ER. Additionally, receptor localization varies between species. In humans, the most extreme approaches were presented by Makinen et al. [22] and Cavaco et al. [24]. Makinen et al. suggested that $\mathrm{ER} \alpha$ is not present in human testes, while Cavaco et al. demonstrated their presence in all germ cell types, as well as in Sertoli and Leydig cells. Interestingly, both authors examined subjects of similar age and both had samples taken from patients with obstructive azoospermia, Sertoli cell-only syndrome and hypospermatogenesis. Both studies applied immunohistochemical methods to verify $\mathrm{ER} \alpha$ localization and were supported by the analysis of $\mathrm{ER} \alpha$ mRNA expression (by means of RT-PCR). The analysis performed by Cavaco et al. [24] showed that $\mathrm{ER} \alpha \mathrm{mRNA}$ was found in the testes of men presenting both normal and disrupted spermatogenesis and that it was relatively constant for men with normal spermatogenesis. Makinen et al. [22] did not detect $\mathrm{ER} \alpha \mathrm{mRNA}$ in the testicular tissue of men with normal spermatogenesis, as well as hypospermatogenesis and Sertoli cell-only syndrome. This contradictory result might be due to some methodological issues. Makinen et al. amplified the samples in 35 cycles, while Cavaco et al. amplified the samples in $37 \mathrm{cy}-$ cles, which might be the reason for better detection. Moreover, the different authors used different kits for total RNA isolation from the tissue and different antibodies for immunohistochemistry, as well as different dilutions of the antibodies.

Similar to Makinen et al. [22], Saunders et al. [12] did not detect $\mathrm{ER} \alpha$ protein in human testes (men with non-obstructive azoospermia and after vasectomy) nor primates (marmoset and macaque), although they claimed to find immunolocalized ER $\alpha$ in Leydig cells of rat testes (however, the data was not shown and only mentioned by the authors). Saunders et al. performed $\mathrm{ER} \alpha$ immunolocalization by means of the same antibodies as used by Makinen et al. and they confirmed the results by Western blotting, although they did not use RT-PCR. In turn, Pelletier and ElAlfy [39] observed ER $\alpha$ only in human Leydig cells with no tubular labeling. Strong positive staining for $\mathrm{ER} \alpha$ was observed also with the use of a rabbit polyclonal antibody to human $\mathrm{ER} \alpha$ in early meiotic germ cells, namely zygotene and early pachytene primary spermatocytes and in early elongating spermatids [40]. Lambard et al. [41] identified an ER $\alpha$ isoform variant that lacks exon 4 in human germ cells with the application of RT-PCR with specific primers and by
Western blotting using monoclonal antibodies. In addition, another transcript to the exon I-deleted variant was detected [42]. Thus, either the presence or the absence of ER isoforms (full length or variants) is likely to be related to the various antibodies used, as well as to the origin of the tissues.

The presence of ER $\beta$ in the testis has been shown by many authors. Based on the results showing that the only ER type present in the testis is $\operatorname{ER} \beta[12,43]$, one may conclude that estrogens exert their effect on testes acting exclusively by binding to $\operatorname{ER} \beta$. However, the demonstration of $\mathrm{ER} \alpha$ presence in the human testis by other immunohistochemical studies $[25,38]$, is in contrast with the above mentioned hypothesis and indicates that probably both $\operatorname{ER} \alpha$ and $\operatorname{ER} \beta$ are involved in the estrogen action pathway in the male gonad.

For the purpose of this study, hormonal determinations, spermatogenesis and Leydig cells assessments and morphometric analysis were performed to prove that examined testes had normal function and morphology to exclude testicular disturbances. To the best of our knowledge, this is the first study proving that the testes examined for ER detection had normal testicular structure. Our study, which showed ER $\alpha$ localization in the testes with normal histological structure and function, supports the hypothesis of the involvement of both types of ERs in human testis function. Our results also add weight to the opinion that estrogens take part in the regulation of Leydig and Sertoli cell function. Assuming that these cell types are responsible for spermatogenesis control, estrogens probably have at least an indirect impact on spermatogenesis. However, their direct influence cannot be ruled out and this has been postulated in studies by other authors. Estrogens stimulate proliferation of gonocytes [44, 45], increase the number of spermatogonia A [46], and stimulate DNA synthesis in spermatogonia in the rat [47]. In human testis tissue cultures, estradiol has been shown to act as a germ cell survival factor [40].

The question which should be further addressed is whether $\mathrm{ER} \alpha$ and $\mathrm{ER} \beta$ patterns differ in patients with normal and aberrant spermatogenesis. It seems that expression of ER $\alpha$ mRNA is relatively constant in the testes of patients with differing degrees of disrupted spermatogenesis, while expression of $\operatorname{ER} \beta$ mRNA varies and is lower than the expression of $\mathrm{ER} \alpha$ [24]. However, a comparison of the testes with spermatogenic arrest to those with normal spermatogenesis showed that $\mathrm{ER} \alpha$ expression was lower in testes with aberrant spermatogenesis [48]. According to the authors, this observation may suggest that $\mathrm{ER} \alpha$ (accompanied by androgen receptor) plays a role in the control of spermatogenesis. Further studies are nec- 
essary to explain differences in the cellular localization of various types of estrogen receptors in various defects of spermatogenesis.

\section{Acknowledgements}

Financial support was provided by grants from Medical University of Lodz: 503/1-089-02/503-01, 503/1-089-03/503-01, 507/1-089-03/507-11-406 and 502-03/ /1-089-03/502-14-018. The authors wish to thank $\mathrm{Mr}$ Edward Lowczowski, a native English speaker, for his help in the preparation of this manuscript.

\section{References}

1. Nilsson S, Makela S, Treuter E et al. Mechanisms of estrogen action. Physiol Rev. 2001;81:1535-1565.

2. Galien R, Garcia T. Estrogen receptor impairs interleukin-6 expression by preventing protein binding on the NF-kappaB site. Nucleic Acids Res. 1997;25:2424-2429.

3. Sun J, Meyers MJ, Fink BE, Rajendran R, Katzenellenbogen JA, Katzenellenbogen BS. Novel ligands that function as selective estrogens or antiestrogens for estrogen receptor-alpha or estrogen receptor-beta. Endocrinology. 1999; 140:800-804.

4. O'Donnell L, Robertson K, Jones M, Simpson E. Estrogens and spermatogenesis. Endocr Rev. 2001:289-318.

5. Carreau S, Bourguiba S, Lambard S, Galeraud-Denis I, Genissel C, Levallet J. Reproductive system: aromatase and estrogens. Mol Cell Endocrinol. 2002;193:137-143.

6. Sharpe RM. The roles of oestrogen in the male. Trends Endocrinol Metab. 1998;9:371-377.

7. Couse JF, Korach KS. Estrogen receptor null mice: what have we learned and where will they lead us? Endocr Rev. 1999;20:358-417.

8. Ogawa S, Chester AE, Hewitt SC et al. Abolition of male sexual behaviors in mice lacking estrogen receptors alpha and beta (alpha beta ERKO). Proc Natl Acad Sci USA. 2000;97:14737-14741.

9. Carpino A, Bilinska B, Siciliano L, Maggiolini M, Rago V. Immunolocalization of estrogen receptor beta in the epididymis of mature and immature pigs. Folia Histochem Cytobiol. 2004;42:13-17.

10. Sar M, Welsch F. Oestrogen receptor alpha and beta in rat prostate and epididymis. Andrologia. 2000;32:295-301.

11. Shayu D, ChennaKesava CS, Soundarajan R, Rao AJ. Effects of ICI 182780 on estrogen receptor expression, fluid absorption and sperm motility in the epididymis of the bonnet monkey. Reprod Biol Endocrinol. 2005;3:10.

12. Saunders PT, Sharpe RM, Williams K et al. Differential expression of oestrogen receptor alpha and beta proteins in the testes and male reproductive system of human and non-human primates. Mol Hum Reprod. 2001;7:227-236.

13. Mosselman S, Polman J, Dijkema R. ER beta: identification and characterization of a novel human estrogen receptor. FEBS Lett. 1996;392:49-53.

14. Bilinska B, Schmalz-Fraczek B, Kotula M, Carreau S. Photoperiod-dependent capability of androgen aromatization and the role of estrogens in the bank vole testis visualized by means of immunohistochemistry. Mol Cell Endocrinol. 2001;178: 189-198.

15. Pearl CA, Mason H, Roser JF. Immunolocalization of estrogen receptor alpha, estrogen receptor beta and androgen re- ceptor in the pre-, peri- and post-pubertal stallion testis. Anim Reprod Sci. 2011;125:103-111.

16. Hejmej A, Gorazd M, Kosiniak-Kamysz K, Wiszniewska B, Sadowska J, Bilińska B. Expression of aromatase and oestrogen receptors in reproductive tissues of the stallion and a single cryptorchid visualised by means of immunohistochemistry. Domest Anim Endocrinol. 2005;29:534-547.

17. Bilinska B, Schmalz-Fraczek B, Sadowska J, Carreau S. Localization of cytochrome P450 aromatase and estrogen receptors alpha and beta in testicular cells-an immunohistochemical study of the bank vole. Acta Histochem. 2000;102:167-181.

18. Mizuno K, Kojima Y, Kurokawa S, Kamisawa H, Kohri K, Hayashi Y. Altered expression and localization of estrogen receptors alpha and beta in the testes of a cryptorchid rat model. Urology. 2011;77:251 e251-256.

19. Pelletier G, Labrie C, Labrie F. Localization of oestrogen receptor alpha, oestrogen receptor beta and androgen receptors in the rat reproductive organs. $J$ Endocrinol. 2000;165:359-370.

20. Saunders PT, Fisher JS, Sharpe RM, Millar MR. Expression of oestrogen receptor beta (ER beta) occurs in multiple cell types, including some germ cells, in the rat testis. $J$ Endocrinol. 1998;156:R13-17.

21. van Pelt AM, de Rooij DG, van der Burg B, van der Saag PT, Gustafsson JA, Kuiper GG. Ontogeny of estrogen receptorbeta expression in rat testis. Endocrinology. 1999;140:478-483.

22. Makinen S, Makela S, Weihua Z et al. Localization of oestrogen receptors alpha and beta in human testis. Mol Hum Reprod. 2001;7:497-503.

23. Enmark E, Pelto-Huikko M, Grandien Ket al. Human estrogen receptor beta-gene structure, chromosomal localization, and expression pattern. J Clin Endocrinol Metab. 1997;82:4258-4265.

24. Cavaco JE, Laurentino SS, Barros A, Sousa M, Socorro S. Estrogen receptors alpha and beta in human testis: both isoforms are expressed. Syst Biol Reprod Med. 2009;55:137-144.

25. Shapiro E, Huang H, Masch RJ, McFadden DE, Wu XR, Ostrer H. Immunolocalization of androgen receptor and estrogen receptors alpha and beta in human fetal testis and epididymis. J Urol. 2005;174:1695-1698.

26. Boukari K, Ciampi ML, Guiochon-Mantel A, Young J, Lombes M, Meduri G. Human fetal testis: source of estrogen and target of estrogen action. Hum Reprod. 2007;22:1885-1892.

27. Carreau S, Wolczynski S, Galeraud-Denis I. Aromatase, oestrogens and human male reproduction. Philos Trans $R$ Soc Lond B Biol Sci. 2010;365:1571-1579.

28. Lambard S, Carreau S. Aromatase and oestrogens in human male germ cells. International Journal of Andrology. 2005;28:254-259.

29. WHO. WHO laboratory manual for the examination of human semen and sperm-cervical mucus interaction. 4 Ed.: Cambridge University Press; 1999.

30. Kramek E, Jastrzebska S, Walczak-Jedrzejowska R et al. Blood lipids may have influence on the emotional well-being in young men. Health. 2010;2: 441-447.

31. Brodowska A, Laszczynska M, Starczewski A, Karakiewicz B, Brodowski J. The localization of estrogen receptor alpha and its function in the ovaries of postmenopausal women. Folia Histochem Cytobiol. 2007;45:325-330.

32. De Kretser DM, Holstein AF. Testicular biopsy and abnormal germ cells. Mosby, St. Louis; 1976. 332-343.

33. Guminska A, Oszukowska E, Kuzanski W et al. Less advanced testicular dysgenesis is associated by a higher prevalence of germ cell neoplasia. Int J Androl. 2010;33:e153-162. 
34. Holstein AF, Roosen-Runge EC, Schirren CS. The testis biopsy. In: Illustrated Pathology of Human Testes. Berlin: Grosse Verlag; 1988.

35. Gundersen HJ, Bagger P, Bendtsen TF et al. The new stereological tools: disector, fractionator, nucleator and point sampled intercepts and their use in pathological research and diagnosis. APMIS. 1988;96:857-881.

36. Steinberger E, Steinberger A. The testis: growth versus function. In: Regulation of Organ and Tissue Growth. New York: Academic Press; 1972.

37. Weinbauer GF, Gromoll J, Simoni M, Nieschlag E. Physiology of testicular function. In: Andrology. Male Reproductive Health and Dysfunction. Berlin, Heidelberg, New York: Springer; 2001.

38. Taylor AH, Al-Azzawi F. Immunolocalisation of oestrogen receptor beta in human tissues. J Mol Endocrinol. 2000;24: 145-155.

39. Pelletier G, El-Alfy M. Immunocytochemical localization of estrogen receptors alpha and beta in the human reproductive organs. J Clin Endocrinol Metab. 2000;85:4835-4840.

40. Pentikainen V, Erkkila K, Suomalainen L, Parvinen M, Dunkel L. Estradiol acts as a germ cell survival factor in the human testis in vitro. J Clin Endocrinol Metab. 2000;85:20572067.

41. Lambard S, Galeraud-Denis I, Saunders PT, Carreau S. Human immature germ cells and ejaculated spermatozoa contain aromatase and oestrogen receptors. J Mol Endocrinol. 2004;32:279-289.
42. Flouriot $\mathrm{G}$, Brand $\mathrm{H}$, Denger $\mathrm{S}$ et al. Identification of a new isoform of the human estrogen receptor-alpha (hER-alpha) that is encoded by distinct transcripts and that is able to repress hER-alpha activation function 1. EMBO J. 2000;19:4688-4700.

43. Saunders PT, Millar MR, Macpherson S et al. ERbeta1 and the ERbeta2 splice variant (ERbetacx/beta2) are expressed in distinct cell populations in the adult human testis. J Clin Endocrinol Metab. 2002;87:2706-2715.

44. Li H, Papadopoulos V, Vidic B, Dym M, Culty M. Regulation of rat testis gonocyte proliferation by platelet-derived growth factor and estradiol: identification of signaling mechanisms involved. Endocrinology. 1997;138:1289-1298.

45. Thuillier R, Mazer M, Manku G, Boisvert A, Wang Y, Culty M. Interdependence of platelet-derived growth factor and estrogen-signaling pathways in inducing neonatal rat testicular gonocytes proliferation. Biol Reprod. 2010;82:825-836.

46. Kula K. Induction of precocious maturation of spermatogenesis in infant rats by human menopausal gonadotropin and inhibition by simultaneous administration of gonadotropins and testosterone. Endocrinology. 1988;122:34-39.

47. Wahlgren A, Svechnikov K, Strand ML et al. Estrogen receptor beta selective ligand 5alpha-Androstane-3beta, 17beta-diol stimulates spermatogonial deoxyribonucleic acid synthesis in rat seminiferous epithelium in vitro. Endocrinology. 2008;149:2917-2922.

48. Wang G, Gu SY, Chen KN et al. Expression of estrogen receptor alpha in the testis of infertile men with spermatogenic arrest. Zhonghua Nan Ke Xue. 2011;17:27-31.

Submitted: 11 April, 2012

Accepted after reviews: 30 July, 2012 